\title{
A Study of the Relationship among Performance Contracting, Measurement and Public Service Delivery in Kenya
}

\author{
Richard E. Ndubai, Isaac M. Mbeche, Ganesh P. Pokhariyal ${ }^{*}$ \\ School of Business and School of Mathematics, University of Nairobi, Nairobi, Kenya \\ Email: *Pokhariyal@uonbi.ac.ke
}

How to cite this paper: Ndubai, R.E., Mbeche, I.M. and Pokhariyal, G.P. (2016) A Study of the Relationship among Performance Contracting, Measurement and Public Service Delivery in Kenya. Open Access Library Journal, 3: e2850.

http://dx.doi.org/10.4236/oalib.1102850

Received: August 23, 2016

Accepted: September 27, 2016

Published: September 30, 2016

Copyright $\odot 2016$ by authors and Open Access Library Inc.

This work is licensed under the Creative Commons Attribution International

License (CC BY 4.0).

http://creativecommons.org/licenses/by/4.0/

c) (i) Open Access

\begin{abstract}
The aim of this study was to establish the factors influencing improvement in performance and delivery of public services. Thus, the paper studied the effect of performance contracting and measurement on public service delivery in Kenya. The public services considered in the study included ministries, state corporations, local authorities and tertiary institutions, with a total of 470 public agencies. The crosssectional survey design was used. The study is based on performance evaluation results compiled over the period between 2004 and 2011. Using regression analysis, it was found that performance measurement was critical to improvement in public service delivery and explained 73.6 percent of improvement in service delivery, as evidenced by independent measurement of customer satisfaction with the services delivered by the public sector.
\end{abstract}

\section{Subject Areas}

Social Issues and Public Policy, Sociology

\section{Keywords}

Performance Contracting, Performance Measurement, Performance Improvement, Service Delivery, Customer Satisfaction

\section{Introduction}

The key challenge that governments have been grappling within the pursuit of better service delivery over the past three decades has been the question of developing a flexible yet powerful model of performance management, measurement and improvement. Such a model needs to be grounded in theory, supported by research, and able to 
communicate complex relationships, while maintaining simplicity and should be sensitive to transactional relationships across performance levels (that is, individual, group, organizational and external impact).

Many government dispensations, in attempts to transform their public services, have developed systems that involve employees in improving organizational effectiveness by focusing their attention on achieving the organization's mission and strategic goals. These are essentially performance management systems designed for implementing strategy by communicating organizational goals and objectives, reinforcing individual accountability for meeting those goals, and tracking individual and organizational performance results. These are however, largely tools that address the immediate performance shortfalls, without necessarily meeting the criteria of models that are both theoretically sound and need attention of practitioners. There are different types of performance management and measurement frameworks, with variants of the core performance management tools, particularly measurement and evaluation. The bulk of these are however, designed for revenue and profit generating organizations. Few other systems place greater emphasis on the strategic management processes with little regard for measurement and evaluation.

The Balanced Score Card and the Performance Contract are the most commonly known and used: the former is largely in the corporate sector and the latter mainly in the public sector. The Performance Contract is a management control system tool that defines the strategic direction, identifies organizational goals, decomposes strategic objectives into measurable performance indicators as well as targets and defines objective methodologies for measuring progress towards achievement of the targets. It therefore, encapsulates the full range of the key attributes of managing, measuring and improving performance. The objective of performance contracting is to improve enterprise performance towards its goals, and aims to bring private enterprise conditions into public enterprises and to encourage initiative, innovation and the spirit of entrepreneurship for the purpose of achieving targeted results effectively and efficiently. Unlike privatization, where public assets are disposed off, the policy seeks to privatize the public sector style of management. It is, in essence, an attempt to move the public sector style of management away from "control by procedures"” to "control by results" (Trivedi, 1994) [1]. The system addresses three of the key problems that public enterprises faces, they are: ill-defined and un-reconciled goals, political and bureaucratic interventions in operational decision-making and management rewards which are fixed irrespective of effort or results (Bennet, 1990) [2]. The objective of this research was to study the factors influencing improvement in the performance and service delivery in Kenyan public services, with a hypothesis to be tested.

\section{Literature Review}

Performance measurement is the most important element in any performance management, measurement and improvement system, including performance contracting. In explaining the distinction between performance management and performance mea- 
surement (Nathan, 2009) [3], stated that the utility of performance management practices is predicated on sound performance measurement system and that the latter should be seen as a prerequisite for effective management. Geniat and Libert (2002) [4] opined, fairly correctly, that "without the capacity to measure, we would be uncertain, literally, as to where we stood and where we are going. We would not know whether we are rich or poor, hot or cold, old or young. The very word 'measure' pervades all fields and you can't make decisions, connections, money, or music without true measurements". To a fairly significant extent, the way we measure success in turn determines the success we attain. Activities, events and programs, which cannot be measured cannot also be easily replicated, managed, or even appreciated. According to Garvin (1993) [5], if something cannot be measured, it cannot be managed. Lebas (1995) [6] goes to the extreme of negating the existence of management without measurement. Performance measurement is a key component of performance management systems and is employed primarily to improve organizational performance and service delivery.

It has been argued that there is a distinct linkage between organizational performance and excellence, in public service delivery. In exploring deliverables as a concept, Langdon (2000) [7] described outputs as synonymous with deliverables of performance. Furthermore, he contended that an output is the reason for the existence of a business or organization. He further stated that output has a consequence, such that the result of the output being interpreted as that which is delivered. He explained that to produce output and consequence there is need for reason and resources, called inputs such as materials, ideas, knowledge and equipment. First, a reason is needed for doing the performance, which comes in the form of a task of some kind. For example, the business unit identifies a customer need, then an order initiates a core process to deliver what the customer wants and finally a work group receives its assignment to meet this need. A manager asks individuals to do their part to produce the output. A service delivered is an outcome resulting from actions directed at making available tangible products for disposal purposes.

Hudson (2006) [8] contends that public services are collectively rendered through government machinery commonly known as departments. Collective units (comprised of employees) within this machinery have to be managed effectively, efficiently and economically. It is on this basis that the collective units are expected to perform at a particular level to measure the type of service delivered against the recipients' expectations. The level of performance by collective units will ultimately represent the level of service delivery. This logic formed the foundation of this study, that excellence in service delivery is predicated on and influenced by improvement in operational performance, while the latter is predicated on measurement as a prerequisite.

\section{Performance Contracting in Kenya}

Performance contracting was introduced in Kenya in 2004 as a set of tools for managing, measuring and improving the performance of the public service. As has been the case in many countries, the principal objective was to create competitive advantage for 
the country by addressing the problems of inefficiencies in the exploitation and use of public resources, and an unresponsive service delivery culture. This was to change remarkably when performance contracting became operational by, in addition, re-focusing public service management from inputs, processes, procedures, and activities, to results (outputs, outcomes and impacts). As a result the performance of public sector institutions, the economy improved rapidly with the economic growth rate rising from 0.4 percent in 2002 to of 7.1 percent in 2007.

Performance contracting in Kenya was founded on five year institutional strategic plans, which were, in turn, linked to the national vision and was built around clear performance criteria, indicators and targets. This included an elaborate measurement and evaluation system which compares achievement on freely negotiated performance targets with actual achievement. The subsequent evaluation examined the various factors affecting performance. Although performance contracting was introduced in the country in 2004, it was not until the financial year 2005/06 that citizens' service charters, and the concomitant requirement for service-oriented public agencies to carry out annual customer satisfaction surveys, thereby paving the way for measurement of various aspects of service delivery that yield to customer satisfaction, began to take root. Accordingly, ministries, state corporations, and local authorities that were on performance contract began to incorporate "customer satisfaction" as a key performance indicator, under the "service delivery" criterion in their performance contracts in the financial year 2006/07. It was therefore, not until 2006/07 that measurement and evaluation incorporating "customer satisfaction" was carried out. Tertiary institutions came on board in 2007/08.

Improvement in performance, impelled to a significant extent by measurement, informs the quality, accessibility, affordability and speed of public services. Performance improvement is engendered when operations are managed under a performance management, measurement and improvement regime that has an elaborate measurement system because, as Osborne and Gaebler (1992) [9] state, "what gets measured gets done". Brown et al. (2001) [10] state that "people make decisions and do their work at least partly based on how they will be evaluated. As a result, they tend to improve in performance aspects that will be measured and rewarded, rather than in un-measured aspects, even if these do not necessarily support organizational goals and customer satisfaction". Many governments have yet to recognize the power of measurement in driving performance improvement. Until 2004, the public sector in Kenya was not an exception. The closest it came to measurement was the performance appraisal system that focused on largely subjective attributes to measure the performance of individual employees. Improvement in organizational performance and service delivery define the framework that drives creation of competitive advantage for countries. Competitive advantage driven by public sector efficiency and effectiveness and customer centric approach to public sector governance has been to address the missing link that defines the difference in economic and social advancement between virtually resource-deficit countries and resource-abundant nations, the latter mainly in the developing world. Gov- 
ernments have critical roles to play in the creation of competitive advantage for respective countries. According to Porter (1990) [11], this role entails acting as a catalyst and challenger to encourage and even push companies to raise their aspirations and move to higher levels of competitive performance, stimulating early demand for advanced products, focusing on specialized factor creation, and stimulating corporate rivalry by limiting direct cooperation and enforcing anti-trust regulations. Effective execution of the role requires an efficient and effective public service, the performance of which forms the basis for measurement and improvement. This then, is about performance improvement driven by an empowered and efficient public service. This study was therefore, prompted by the need to establish the influence performance contracting, anchored on performance measurement would have on improvement of performance and delivery of public services. However, the performance of both public and private sector, to a large extent, depends on the political stability prevailing in the country, as was reported in the case of Lesotho (Manchafalo, 2014 [12]). On the other hand, economic uncertainty, rapidly changing social and cultural value systems and advancements in technology, in general, influence the performance of the organizations (Farrel \& Goodman, 2013) [13].

\section{Research Methodology}

This study employed a cross-sectional design whereby the research problem was clearly identified, previous published literature reviewed and synthesized, and the hypotheses relating to the research questions specified. The hypothesis that formed the basis of the study was that, there is no significant relationship between performance contracting and measurement and public service delivery in Kenya.

The Kenyan Constitution that was promulgated in August 2010 significantly altered the landscape of the structure of government agencies. Requirements in the Constitution precipitated wide ranging restructuring of the mainstream civil service resulting in the merger of ministerial functions, thereby reducing the number of ministries and accounting departments from 46 to 18 , the virtual abolition of local authorities and the subsequent emergence of County Governments. The data available for the study were therefore in regard only to agencies that existed in the old, constitutional structure. The study relied on secondary data which was already available. In 2010/11, which was the terminal year for data collection and analysis in this paper, the number of public agencies on performance contract was 470 , made up of 46 ministries and accounting departments, 178 state corporations, 175 local authorities and 71 tertiary institutions. The distribution is shown in the table below. The focus of the study was the entire population of 470 public agencies. Further, the various categories of public agencies had, by 2010/11, been on performance contract for differing periods; these are 6 years for both ministries and state corporations, 5 years for local authorities and 4 years for tertiary institutions. The data from agencies was organized, summarized and collated in the manner that linked with research question and subsequently analyzed using descriptive and inferential statistics. 


\section{Data Analysis and Results}

The study focused on the five years of 2006/07, 2007/08, 2008/09, 2009/10 and 2010/11, during which period customer satisfaction in the majority of the above categories of public agencies was measured. The distribution of the various categories of institutions is shown in Table 1.

The performance evaluation methodology in Kenya graded excellence on a composite-scoring scale ranging from 1 to 5 with 1 denoting the upper limit of "excellent" achievement and 5 representing the lowest limit of "poor" achievement. The composite scores were inverted, in order to give a rising visual effect to positive achievement and a declining visual effect to poor achievement. Further, the composite scores in each of the four categories of public agencies were averaged for each year to contain the data within manageable parameters.

The analysis was carried out using the Statistical Package for Social Sciences (SPSS), version 21. Descriptive statistics was carried out to summarize the data and to bring out variability and dispersion using the mean, the standard deviation and the coefficient of variation. Correlation coefficients were computed to establish the relationship between the study variables and the extent to which the dependent variable could be predicted from the independent variable, and to derive the regression equation. Linear regression analysis was used to examine the models overall and individual statistical significance by using F-value and t-value, respectively. A model equation was derived for the hypothesis using variables that were significant. Table 2 shows the descriptive statistics of the study's variables.

As indicated in the table, the public sector in Kenya had an average customer satisfaction index of 0.27779 , implying that nearly 72 percent of customers were dissatisfied

Table 1. Distribution of public agencies on performance contract in 2011.

\begin{tabular}{ccc}
\hline Category of MDA & No. & Percent \\
\hline Ministries and Accounting Departments & 46 & 9.79 \\
State Corporations & 178 & 37.87 \\
Local Authorities & 175 & 37.23 \\
Tertiary Institutions & 71 & 15.11 \\
Total & 470 & 100.00 \\
\hline
\end{tabular}

Source: Organization of government; Office of the president.

Table 2. Descriptive statistics of the study's variables.

\begin{tabular}{cccccc}
\hline Variable & T-Value & Sig. (2-Tailed) & Mean & Std. Deviation & CV \% \\
\hline Performance Measurement & 37.720 & 0.000 & 2.65439 & 0.27255 & 10.27 \\
Customer Satisfaction & 8.699 & 0.000 & 0.27779 & 0.12368 & 44.52 \\
Global Competitiveness & 157.181 & 0.000 & 3.69800 & 0.09112 & 2.46 \\
Political Stability & -47.656 & 0.000 & -1.31533 & 0.10690 & -8.13 \\
\hline
\end{tabular}


with the public sector service delivery. Among other variables pitted against customer satisfaction, performance measurement had the highest dispersion $(S D=0.27255)$ across the public sector made up of ministries, state corporations, local authorities and tertiary institutions. The coefficient of variation was computed to show the variability in the data of the study parameters. Customer satisfaction shows the greatest variability $44.52 \%$, followed by performance measurement $10.27 \%$.

The regression analysis further provided an estimate equation to predict the magnitude of the dependent variable (customer satisfaction) and give values for the predictor variables.

In addition, $\mathrm{t}$-test and $\mathrm{p}$-values were used to determine individual significance of the results of the analysis. Assessment of the overall robustness and significance of the regression models was done using the F-test and $p$-values. Pearson correlation coefficient, $R^{2}$, beta coefficients, and $p$ values were computed.

In order to establish the relationship between performance contracting and measurement and service by public agencies, regression and correlation analysis were used to establish the influence that performance contracting and measurement had on customer satisfaction. A correlation analysis of the study variables (Table 3 ) indicated that performance measurement was highly correlated with customer satisfaction $(R=0.858)$ and the relationship was significant at 99 percent confidence level. This high relationship brings out the importance of having a performance measurement system to establish performance levels and to monitor how customers are served in the public sector.

\subsection{Performance Measurement and Customer Satisfaction}

The critical essence of the performance contracting system is the capacity to measure performance. The results of the analysis carried out to establish the relationship between performance measurement and customer satisfaction are shown in Table 4. The results show that performance measurement had a strong positive relationship $(\mathrm{R}=$ 0.858 ) with customer satisfaction. Performance measurement explained 73.6 percent

Table 3. Correlation analysis of the study variables.

\begin{tabular}{|c|c|c|c|c|c|}
\hline & & $\begin{array}{l}\text { Performance } \\
\text { Measurement }\end{array}$ & $\begin{array}{l}\text { Customer } \\
\text { Satisfaction }\end{array}$ & $\begin{array}{c}\text { Global } \\
\text { Competitiveness }\end{array}$ & $\begin{array}{l}\text { Political } \\
\text { Stability }\end{array}$ \\
\hline Performance & Pearson Correlation & 1 & & & \\
\hline Measurement & Sig. (2-tailed) & & & & \\
\hline Customer & Pearson Correlation & $0.858^{* *}$ & 1 & & \\
\hline Satisfaction & Sig. (2-tailed) & 0.000 & & & \\
\hline Global & Pearson Correlation & 0.086 & 0.159 & 1 & \\
\hline Competitiveness & Sig. (2-tailed) & 0.760 & 0.571 & & \\
\hline Political & Pearson Correlation & 0.099 & -0.134 & -0.468 & 1 \\
\hline Stability & Sig. (2-tailed) & 0.724 & 0.633 & 0.079 & \\
\hline
\end{tabular}

${ }^{* *}$ Correlation is significant at the 0.01 level (2-tailed). 
Table 4. Relationship between performance measurement and customer satisfaction.

\begin{tabular}{|c|c|c|c|c|c|c|}
\hline \multicolumn{7}{|c|}{ Model Summary } \\
\hline Model & $\mathrm{R}$ & R Square & \multicolumn{2}{|c|}{ Adjusted R Square } & \multicolumn{2}{|c|}{ Std. Error of the Estimate } \\
\hline 1 & $0.858^{\mathrm{a}}$ & 0.736 & \multicolumn{2}{|c|}{0.715} & \multicolumn{2}{|c|}{0.06599} \\
\hline \multicolumn{7}{|c|}{ Predictors: (constant), performance measurement. } \\
\hline & & Sum of Squares & $\mathrm{Df}$ & Mean Square & $\mathrm{F}$ & Sig. \\
\hline & sion & 0.158 & 1 & 0.158 & 36.176 & $0.000^{\mathrm{b}}$ \\
\hline \multirow[t]{2}{*}{1} & lual & 0.057 & 13 & 0.004 & & \\
\hline & & 0.214 & 14 & & & \\
\hline
\end{tabular}

b. Predictors: (constant), performance measurement.

\begin{tabular}{|c|c|c|c|c|c|c|}
\hline & \multirow{2}{*}{ Model } & \multicolumn{2}{|c|}{ Unstandardized Coefficients } & \multirow{2}{*}{$\begin{array}{c}\text { Standardized Coefficients } \\
\text { Beta }\end{array}$} & \multirow{2}{*}{$\mathrm{T}$} & \multirow{2}{*}{ Sig. } \\
\hline & & B & Std. Error & & & \\
\hline \multirow[b]{2}{*}{1} & (Constant) & -0.755 & 0.173 & & -4.376 & 0.001 \\
\hline & Performance Measurement & 0.389 & 0.065 & 0.858 & 6.015 & 0.000 \\
\hline
\end{tabular}

$\left(\mathrm{R}^{2}=0.736\right)$ of customer satisfaction levels with the remaining 26.4 percent accounted for by other factors. The F-value for the model was 36.176 and the derived $p$-value was 0.000 . Since the derived $p$-value of 0.000 was less than 0.05 , with a table value of 2.145 as compared to a calculated value of 6.015 , the hypothesis was rejected. Hence, performance measurement had a significant relationship with customer satisfaction. The performance measurement variable had a $t$-value of 6.015 and was significant.

The study demonstrated the power of performance measurement in impelling performance improvement, and further that performance improvement leads to improvement in service delivery denominated in the changing levels of customer satisfaction.

A model equation of the relationship is described as follows:

Customer satisfaction $=-0.775+0.389$ Performance Improvement.

This shows that a unit change in performance improvement, impelled by performance measurement, will result in customer satisfaction changing by a factor of 0.389 . In the absence of performance improvement, a constant customer satisfaction of negative 0.775 would be realized.

The key finding then was that performance measurement is critical to improvement in public service delivery, and accounts for or explains 73.6 percent of improvement in service delivery, with a unit change in measurement of performance resulting in a change of 0.389 in customer satisfaction.

\subsection{Discussion}

Performance contracting as practiced and implemented in the public service in Kenya is essentially a performance management, measurement and improvement system. The 
essence of the system is in ensuring the measurement and improvement of the performance of all key organizational factors by focusing on multiple management perspectives, thereby bringing out the assertion by Hayes and Clark (1986) [14], that "in reality, the productivity a firm achieves is a function of how efficiently it uses all its inputslabor, capital, technology and energy - to produce outputs". Further, by establishing that performance measurement is critical to improvement in public service delivery, the findings of this study tend to be consistent with assertions made by other authors on performance management. Osborne and Gaebler (1992) [9] contend that what gets measured gets done, while Brown et al. (2001) [10] state that people make decisions and do their work at least partly based on how they will be evaluated. As a result, they tend to improve in performance aspects that will be measured and rewarded, rather than in un-measured aspects, even if these do not necessarily support organizational goals and customer satisfaction.

In 1997, 2006, 2010 and 2012 four separate studies related to the subject of our study were conducted in different countries. Anderson et al. (1997) [15] studied customer satisfaction, productivity and profitability in respect to both goods and services, using the Swedish Customer Satisfaction Barometer (SCSB) and found that there was positive correlation between the undertaken variables. These findings match with our findings. Hudson (2006) [8] explored whether performance management (which encompasses measurement) is a precondition for organizational performance and improvement in public service delivery in South Africa. The study showed no significant correlation between the parameters and was therefore in contradiction with our study. Hu and Jen (2010) [16] conducted a study to explore the antecedents of customer satisfaction and loyalty for the freight shipping industry in Taiwan, from the viewpoint of business customers. The study established that relational performance and service quality are significant predictors of satisfaction and also that relational performance, established through measurement, is an antecedent of service quality and satisfaction. This is largely consistent with the findings of our study. Adams, et al. (2012) [17] investigated the linkages between customer service, customer satisfaction, and firm performance in the airline industry in the USA. The investigation showed a positive relationship among the variables and, significantly, that customer satisfaction increases with service performance, both established through measurement. It was reported from Lesotho (Manchafalo, 2014 [12]) that the tourism industry recorded drastic decline in the inflow of the tourists as well decreased spending by corporate and individual customers because of political instability in the Kingdom of Lesotho Further businesses reported downturn in revenues for lodging, food, events and other hospitality services.

Braverman \& Kuntz (2012) [18] observed that innovative governments are making it easier for citizens to access public services. In addition, the most forward-thinking governments are starting to master the shift from simply administering services, to regularly engaging and empowering citizens, involving them in the design and, in some cases, the delivery of the services. This shift is not just about increasing choice and well being; it is also about boosting government productivity, with the help of technology and the use of open data. 
Farrell \& Goodman (2013) [13] explored the daunting challenges governments are facing today. It observed that in a world characterized by macroeconomic uncertainty, rapid social change and technological innovation, citizens' expectations of what government ought to deliver are rising. On the other hand, governments are hampered by unsustainable debt burdens and shrinking budgets. For example, by 2013, the ratio of general government debt to Gross Domestic Product (GDP) for member states of the OECD exceeded 100 percent (OECD Economic Outlook No. 93, June 2013). Meanwhile, public trust in government is eroding and against this backdrop, not only must governments do more with less, they must do so in highly visible ways, if they are to regain the faith of their constituents. Guerra-López \& Hutchinson (2013) [19] noted that performance contracting system is fairly sensitive to transactional relationships across performance levels (that is, individual, group, organizational, and external impact) and contexts. These findings tend to agree with our study.

\subsection{Conclusion}

The constituency most affected by the performance of the government is essentially the citizen, who is also the tax payer. When a government is able to identify and manage the factors that influence and affect service delivery, it is better able to relate with the citizen, and to improve customer satisfaction with public services. Moreover, identifying the key factors affecting performance helps in not only focusing of public resources in the right areas, but also refocusing of managerial effort to address customer-centric issues. The findings of the study therefore point to the need for policy makers to recognize the power of performance measurement in impelling performance improvement, as the latter affects the delivery of public services, and to ensure that performance management practices in the public service are grounded on sound performance measurement systems. This study was done, for the old structure of Kenyan government. Therefore, in future, such study can be conducted with the new structure having county governments.

\section{References}

[1] Trivedi, P. (1994) Memorandum of Understanding-An Approach to Improving Public Enterprise Performance. International Management Publishers, New Delhi.

[2] Bennett, W. (1990) Repairing the News: A Case Study of the News Paradigm. Journal of Communication, 35, 50-68.

[3] Nathan, R.P. (2009) Point/Counterpoint. Journal of Policy Analysis and Management, 26, 496-516. http://dx.doi.org/10.1002/pam.20443

[4] Geniat, M.A. and Libert, F.H. (2002) Communicating and Controlling Strategy: An Empirical Study of the Effectiveness of the Balanced Scorecard. Journal of Management Accounting Research, 13, 47-90.

[5] Garvin, D.A. (1993) Manufacturing Strategic Planning. California Management Review, 35, 85-106. http://dx.doi.org/10.2307/41166756

[6] Lebas, M.J. (1995) Performance Measurement and Performance Management. International Journal of Production Economics, 41, 23-35. 
http://dx.doi.org/10.1016/0925-5273(95)00081-X

[7] Langdon, D.G. (2000) Aligning Performance: Improving People, Systems, and Organizations. Jossey-Bass Pfeifer, San Francisco, CA.

[8] Hudson, M.M. (2006) Performance Management and Service Delivery in the Department of Water Affairs and Forestry (DWAF). Postgraduate Thesis Paper.

[9] Osborne, D. and Gaebler, T., Eds. (1992) Reinventing Government. How the Entrepreneurial Spirit Is Transforming the Public Sector. Penguin Books USA Inc., New York.

[10] Brown, S., Blackmon, K., Paul Cousins, P. and Maylor, H. (2001) Operations Management-Policy, Practice and Performance Improvement.

[11] Porter, M.E. (1990) The Competitive Advantage of Nations. Harvard Business Review, 68, 73-93. http://dx.doi.org/10.1007/978-1-349-11336-1

[12] Manchafalo, M. (2014) Lesotho Times. 17. 23rd October 2014.

[13] Farrell, D. and Goodman, A. (2013) Government by Design: Four Principles for a Better Public Sector. Mackinsey \& Company, Waltham, MA.

[14] Hayes, R.H. and Clark, K.B. (1986) Why Some Factories Are More Productive Than Others. Harvard Business Review, 64, 66-73.

[15] Anderson, E.W., Fornell, C. and Rust, R.T. (1997) Customer Satisfaction, Productivity, and Profitability: Differences between Goods and Services. Marketing Science, 16, 129-145. http://dx.doi.org/10.1287/mksc.16.2.129

[16] HU, K.C. and Jen, W. (2010) From the Viewpoint of Business Customers to Explore the Antecedents of Satisfaction and Loyalty for Freight Shipping Industry in Taiwan. Journal of the Eastern Asia Society for Transportation Studies, 8, 10-11.

[17] Adams, S.B., Dong, Y., Dresner, M. and Robert, H. (2012) Linkages between Customer Service, Customer Satisfaction and Performance in the Airline Industry: Investigation of NonLinearities and Moderating Effects. Transportation Research Part E: Logistics and Transportation Review, 48, 743-754.

[18] Braverman, E. and Kuntz, M. (2012) Innovation in Government: India and Estonia. McKinsey \& Company, New Delhi.

[19] Guerra-López, I. and Hutchinson, A. (2013) Measurable and Continuous Performance Improvement: The Development of a Performance Measurement, Management and Improvement System. Performance Improvement Quarterly, 26, 159-173.

http://dx.doi.org/10.1002/piq.21151 
Submit or recommend next manuscript to OALib Journal and we will provide best service for you:

- Publication frequency: Monthly

- 9 subject areas of science, technology and medicine

- Fair and rigorous peer-review system

- Fast publication process

- Article promotion in various social networking sites (LinkedIn, Facebook, Twitter, etc.)

- Maximum dissemination of your research work

Submit Your Paper Online: Click Here to Submit

Or Contact service@oalib.com 